\title{
RICH HERITAGE OF ANCIENT HINDU WISDOM
}

\author{
Y V Subba Rao ${ }^{1}$ \\ ${ }^{1}$ Executive Engineer (Retired) University Science and Instrumentation Centre, Sri Venkateswara University, Andhra \\ Pradesh, Tirupati, India
}

Received 8 May 2021

Accepted 20 May 2021

Published 31 May 2021

Corresponding Author

Y V Subba Rao, yvsubbarao2004@ yahoo.com

DOI 10.29121/

granthaalayah.v9.i5.2021.3946

Funding: This research received no external funding. Retired from service 2 decades back, now an octogenarian. Presently not associated with any institution

Copyright: (C) 2021 The Author(s). This is an open access article distributed under the terms of the Creative Commons Attribution License, which permits unrestricted use, distribution, and reproduction in any medium, provided the original author and source are credited.

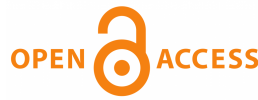

\section{ABSTRACT}

Vedic Paradigm is a survey of Vedic literature of 'Para Vidya' of the unlimited realm of transcendental knowledge besides 'Apara Vidya' knowledge of material sciences has stupendous knowledge of science latent in them. Instead of exploring the science latent in the vedic literature by scientific management, Indian academics in support with some more from other countries together chose to nomenclature the rich heritage of ancient Hindu wisdom as "Nationalistic Pseudoscience". The present study disproved this unwarranted criticism. 'Jyotish', one of the six Vedangas and ancillary of the four Vedas since antiquity, taken here in this paper as one example as an embodiment of all modern sciences latent.'Jyotish' is defined as the study of the effect of Astrophysics on the earth and all life living on it affording a clue to birth, death, rebirth and liberation of soul while affording proof that the entire subject together with the genesis of its principles is based on sunlight, the electromagnetic wave of light and radiation characterized by frequency or wavelength of oscillations.

Keywords: Para Vidya, Apara Vidya, Jyotish, Vedanga, Vedas, Electromagnetism

\section{INTRODUCTION}

Interest in astronomy stretches back to the Stone Age. 'Jyotish' in Sanskrit means Astrology and Astronomy, one of the six Vedangas and ancillary of the four Vedas since antiquity is an innocent hobby. It harms none but elevates all. A person with knowledge in Astrology grows taller in spiritual practice to attain liberation, the justification of human life. Indian Academics seeking support of some academics of western countries together nomenclature the rich heritage of ancient Hindu wisdom as "Nationalistic Pseudoscience". In this context, I venture to be proud of my country, its religion and I have love for it. However, the dominant religion in India is Hinduism. Hinduism is a major religious and cultural tradition of South Asia, which developed from Vedic religion. Hinduism is the greatest of all religions where its vedic literature comprises both spiritual sciences and material sciences. Hinduism accommodates 
all other religions and holds that God is one. Hinduism does not contradict science since both religion and science endeavour for the same truth. The scientific Hindu, in fact, has been the bane of our land and its rich heritage for the past millennium. This means that all Hindus are unscientific as for as Hinduism is concerned since no effort, whatsoever has been put by them with their scientific supremacy to earth the rationale behind the valuable information provided in the Vedic Paradigm applying the principles of scientific management. Scientific management demands everything is suspected initially, is thoroughly examined and analysed to its depth and the truth latent in the matter is unearthed for the benefit of posterity.

The 'Vedic Paradigm' consists of 'Para Vidya' and 'Apara Vidya'. Hinduism holds that even souls evolve. Para Vidya is all about transcendental consciousness while Apara Vidya is all about material sciences beneficial to the human beings to evolve from being a stone-age man to the level of a person bordering on the divinity and ultimately transforms himself to being 'Divine'. The future of country's dominant Hinduism is directly under attack mostly by its own highly scientific educated population with their unnecessary disbeliefs of the rich heritage of Hindu wisdom without analysing. Let us explore the truth of the matter with instances. In 2004, the University Grants Commission has proposed that the study of Vedic Astrology be offered as an academic discipline at colleges and universities in India to rejuvenate Vedic Astrology in the very land of its glory. Educated unbelievers hold that characterization of astrology for validation as a science is fundamentally different from those on which science is based. The subject matter of astrology is more often dismissed out of hand by the educated, due to a number of preconceptions. The academics wondered why astrology needs to find a place at university. After all, it shows no interest in being linked to fields of science (not to biology, not to psychology, not to statistics, not even to astronomy), or the humanities or the social sciences. As it happens, the think-tank noted from dictionaries in which astrology was dismissed as 'nonsense' and not to be taken seriously. The think-tank felt that astrology needs to gain academic credentials in order to be taken seriously.

\section{INTRODUCING “VEDIC ASTROLOGY” COURSES IN UNIVERSITIES : A LEGAL DISPUTE}

In an endorsement of HRD Minister Murali Manohar Joshi's campaign, the Supreme Court today found no fault with the decision of the University Grants Commission to introduce "Vedic Astrology" courses in universities and dismissed a petition challenging it. A Bench comprising Chief Justice S Rajendra Babu and Justice G P Mathur dismissed a petition filed by scientist $\mathrm{P} M$ Bhargava and others challenging an Andhra Pradesh High Court order dismissing a similar petition. The HRD Minister had been a strong advocate of introduction of astrology as a course at the post-graduation level and for providing platform to students in astrology to do research. The Government had contended that vedic science was part of the Indian culture and heritage and 
formed an important part of our ancient science in which India had made substantial contribution to the world. The petitioners had questioned the decision of UGC in according permission to the Universities for starting the graduate, post-graduate and research courses in "Jyotir Vigyan". The scientist had contended that the guidelines issued by UGC were totally irrational, as vedic astrology could not be held to predict the unforeseen. They had submitted that astrology did not qualify to be subject of study in the University.

\section{DEFINITION OF 'JYOTISH'}

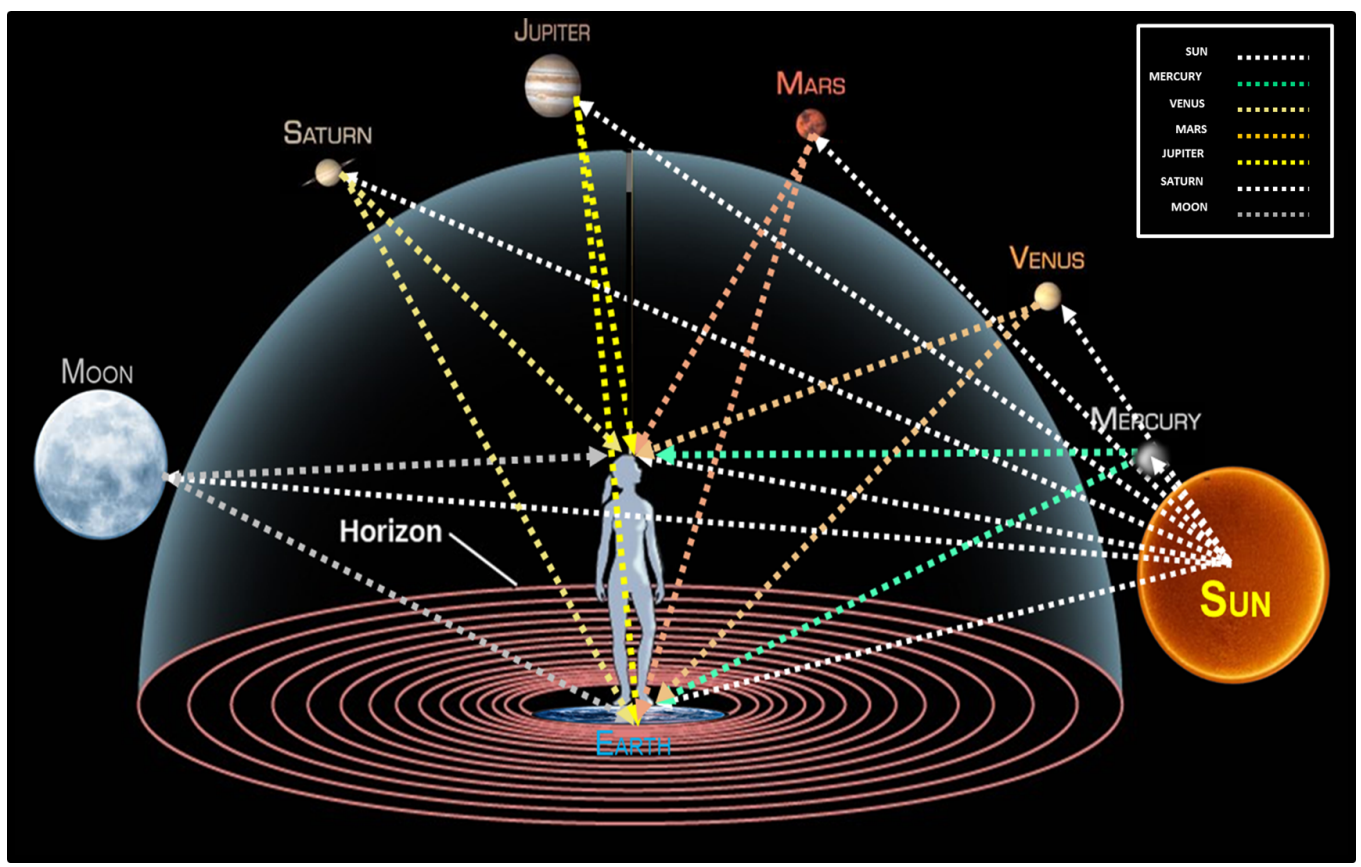

Figure 1 Sunlight on the Earth directly, by Reflection from the Interior Planets, by Deflection and Reflection from the Exterior Planets, and by Modulation through the Lunar Nodes

HindusJyotish"Vedic“Jyotish",VedāngasVedas,"Jyotish”,Vedāngainterior planets, by deflection and reflection from exterior planets and by modulation of moonlight by the two lunar nodes (Figure 1 ).

Also, the selective adaptation of only 27 lunar constellations lying equidistant along the ecliptic out of 88 clusters of stars in the zodiac for its study of the subject of "Jyotish" which are the source of all the inorganic elements of the periodic table Johnson (2019). The stars give out elements at different phases of their life cycle give rise to organic molecules which in turn give rise to life of different species, including humans, from time to time as evidenced in the Geological Time Scale. Further, the genesis of all the principles of "Jyotish", are solely based on the principles of light in physics. In fact, it is not out of place to state that Vedic Astrology is the fruit of Astronomy, Astrophysics, Physics, Astrobiology, Geology, Geophysics, Mathematics, 
Geometry, Philosophy, etc., all of which has common roots in man's ancient past and, as the research of the current day is hinting, is inextricably joined together in the face of a holistic cosmos. The author being an engineer has applied the principles of scientific management and attempted to verify the rationale, rather the truth about the genesis of principles of astrology instead of abandoning it with preconceptions. The author of this article could not but exclaim "eureka" and lost in the wonder of philosophical silence with his researches resulted the scientific basis of astrology. Further, human anatomy and physiology are the mirror reflection of the Solar System. This purports to convert the modern educated unbeliever into a believer of astrology, a perfect science, and enjoy the fruits of fore-knowledge. The uncanny ability of the ancient Hindu sages to see the future, renders Astrology as an unchallengeable universal science with a cosmopolitan outlook without discrimination of caste, creed, colour, sex or nationality.

\section{SUNLIGHT, MATTER, LIFE AND ENERGY IN BIRTH, DEATH, REBIRTH AND BEYOND}

"Jyotish" subject is based on sunlight, an electromagnetic wave of light and radiation. Sunlight transforms, inorganic chemistry available to us in the universe being the outcome of stars into organic chemistry under abiotic conditions, into life and then transforms life into energy in all life living on the earth. Earth pulsates at a frequency of $7.83 \mathrm{~Hz}$ (Schumann Resonance). A $7.83 \mathrm{~Hz}$ frequency is an alpha/theta brainwave frequency in the human brain "What is Schumann Resonance and why it is important for your Health ... (n.d.). This frequency is fundamental to human beings whereas all the other species resonate harmonically to the earth's frequency in evolution. Albert Einstein held that matter is a wrong concept and that everything we have is only energy which is unperceivable. Energy at a lower frequency appears as matter and perceivable. Hinduism holds seven higher worlds with the 'Bhuloka' being the first one. Above 'Bhuloka' is 'Suryamandalam' whose frequency is about $126 \mathrm{~Hz}$; above it is 'Saptarishimandalam' (Ursa Major, a cluster of seven stars in Astronomy), and above it is 'Dhruvamandalam' (Ursa Minor with Polaris being the tail end star in line with two stars, Merak and Dubhe stars, of Ursa Major). The frequency of these 'lokas' is enormously greater than the frequency of the Sun. The correctness of the matter is evidenced by the fact that the space vehicles used for space travel by astronauts are fitted with frequency generators. The frequency of the higher worlds above the 'Suryamandalam' will be ever increasing as one travels to 'Brahmaloka'. Along with the infinite frequency of these lokas, the energy also will be infinite with infinitesimal wave length obeying Einstein's Theory of Special Relativity Equation E = mc ${ }^{2}$ - means "energy equals mass times the speed of light squared." Einstein's equation $\mathrm{E}=\mathrm{mc}^{2}$ shows that energy and mass are interchangeable. In the case of spiritually enlightened persons, the frequency of the soul increases on the termination of mundane existence due mainly to their positive actions in life. Death is inevitable to all 
living. All actions of positive nature increase the frequency of the soul (the sookshma sarira with jivātma) while actions of negative nature decrease the frequency in compliance with Newton's third law of motion, "For every action, there is an equal and opposite reaction." Death is inevitable to all living when the five natural elements with which the body is composed of goes back to the pool. But, where does the energy go? The first law of thermodynamics is a version of the law of conservation of energy, adapted for thermodynamic processes. In general, the conservation law states that the "energy can be transformed from one form to another, but can be neither created nor destroyed." Therefore, it goes to the cosmos like 'atman' in Hinduism, with the soul to one of the higher worlds of matching frequency since souls do evolve according to Hinduism Y. Rao (2020a).

After enjoying the fruits of its meritorious deeds performed here on earth in a higher loka of matching frequency of the soul, it returns to be reborn according to Hinduism (vide Bhagavad Gita, Chapter 9, Verse 21 Large (2003); and vide 'Brihat Samhita' of Varahamihira (520 AD), an Indian Astronomer and Astrologer on 'Meteors' Bhat and M (2010). In 2009, NASA also corroborated with this view when it found readymade kits of life building blocks of DNA in meteorites Callahan et al. (2011). It is, therefore, clear that life in perceivable physical form exists only on earth and nowhere else in the universe and it is a futile exercise and a colossal waste of money running to billions of US Dollars spent in the search for life elsewhere in the universe. Apart from this, the inhabitable planet for such life in physical form perceivable to evolve must be a true reflection of our mother earth, particularly, in terms of its frequency which is difficult to find, if not, impossible.

\section{SCIENCE IN 'JYOTISH'}

- The genesis of all principles of "Jyotish" (VedicAstrology) are based on modern sciences such as Astronomy, Astrophysics, Astrobiology, Mathematics, Metaphysics, Philosophy, Humanities, etc Y. V. Rao (2016).

- Sunlight defines life as an emergent property of matter (Rao, YVS, 2019) Y. V. Rao (2019) Selective adaptation of celestial bodies such as Sun (a star), Moon (satellite of the Earth), Mercury and Venus Interior Planets), Rāhu and Ketu (the two lunar nodes), and Mars, Jupiter and Saturn (exterior planets) - - - all responsible for sunlight on the earth.

- Selective adaptation of 27 lunar constellations out of a cluster of 88 constellations being the source matter in the form of inorganic chemistry of elements.

- The sequence of the lords of the number of 12 signs of the zodiac among the seven entities the sequence of the planets in the solar system starting with sun as the lord of Leo is followed treating the sun and moon as a single entity.

- The positions of Rahu in the sequence of Dasas of Vimsottari Dasa System is determined as the place of 'missing planet' in Titius-Bode Law of Astronomy; geometrical symmetry is followed in the placement of Rāhu and Ketu in the 
sequence of the Dasa system in that Rahu is found as the third planet from the Earth on the right side in the group of exterior planets whereas Ketu is found as the third planet from the earth on the left side in the group of interior planets.

- Dasa years of each planetof Vimsottari Dasa System are 'savana' years meaning a year contains 360 days only. The extents of Dasa years of planets in the Vimsottari Dasa System is a descensional order 'arithmetic sequence' starting from 20 years' extent of Venus Dasa based on the colours of the planets of electromagnetic spectrum colours sequence in the 'Dispersion of Sunlight'.

- Exaltation of planets in 'Jyotish' is based on the principle of 'benefic planets' exalt in 'benefic signs' while 'malefic planets' exalt in 'malefic signs' with the exception of Saturn whose exaltation sign is Libra, a benefic sign, as Saturn is a liaison planet.

- The rationale of special aspects of exterior planets, Mars, Jupiter and Saturn are in accordance with "Einstein's Theory of Deflection of Light". In each of the pair of special aspects of 4 and 8 for Mars, 5 and 9 for Jupiter, and 3 and 10 for Saturn, one house of each planet is the karakatva house of the planet while the other house is the lordship of that house of the planet. Thus, for Mars $4^{\text {th }}$ house is "kshetrakaraka" and $8^{\text {th }}$ house is lordship of Scorpio; for Jupiter, the $5^{\text {th }}$ house is "putrakaraka" and the $9^{\text {th }}$ house is lordship of Sagittarius; and for Saturn, $3^{r d}$ house is 'Ayushkaraka" and the $10^{t h}$ house is lordship of Capricorn.**It must be remembered that all the significations of the houses and the principles are derived assuming Aries as the Lagna (Ascendant or Rising Sign) at the beginning of Svetavarāha Kalpa when all planets were in celestial conjunction in Aries.

- Fully supports Panspermia Origin of Life Rao, (YVS, 2021), "Advanced Panspermia Origin of Life and Evolution," Communicated to Royal Interface Focus Journal. Y. Rao (2021).

- "Life on Earth is adapted to the rotation of our planet" (Jeffrey C. Hall et al., 2017). Hall et al. (2017).

- Lunar magnetism orchestrates human female menstrual cycles in reproduction (Venkata Subba Rao Yeragudipati, 2019) Yeragudipati (2019).

- Horoscopy proves heredity and serves as a forensic tool in disputes of paternity and maternity as striking planetary similarities are observed for parents and their children of their respective birth times similar to matching bands in DNA Fingerprinting establishing heredity (i) Michel Gauquelin, "Planetary Heredity," San Diego, CA: ACS Publications, 1988. Text ISBN 10: 0935127011 / ISBN 13: 978093512701 [311] and (ii) (Subba Rao, Y. V., Ramana Rao, Y. V., 2017) Y. V. S. Rao (2017a).

- The number of $3 \times 10^{6}$ DNA entries required and the number of Astrological charts required to differentiate one from the other are identical. Subba Rao,Y. V, Ramana Rao, Y. V, (2017) Y. V. S. Rao (2017b). 
- Pregnant women spontaneously deliver more often during a Full Moon Ginecol (1997). 10

- Women's Menstrual Cycles Begin More Often During a New Moon "Women's Menstrual Cycles Begin More Often During a New Moon": The Scandinavian Journal" (1986)

- An interesting 1990 study in the journal Psychiatry Research found that bright light at night can help regulate the menstrual cycle. In the study, women with abnormally long cycles of about 45 days who slept with a 100 -watt bulb turned on at night in their bedroom from Day 13 to Day 17 of their cycle successfully shortened their cycles to about 33 days Britannica (1994).

- Unravels the complexity of brain such as consciousness and transcendental consciousness in human. Each of the species living on earth too have a specific frequency of its own resonating with the earth's magnetism (Schuman's Resonance of $7.83 \mathrm{~Hz}$ ) harmonically with the exception human beings, with irreducible complex organs, tuned fundamentally to the natural harmonic frequency of the Earth of $7.83 \mathrm{~Hz}$, arrived last and evolved all over the globe, thus, remains unique from all other species. The earth's frequency of $7.83 \mathrm{~Hz}$ apparently has matched that of the human brain's average alpha frequency. Implementing this design in human beings by any mechanism, other than the one described is beyond comprehension. (Rao, YVS, 2020) Y. Rao (2020b).

\section{CONCLUSION}

Suffice it with many such examples to drive home the point and in conclusion, to silence the critics, mostly the educated unbelievers, and assert that "Jyotish" is defined as the science of study of the effect of sunlight on the Earth and all life living on it including, birth, death, rebirth and ultimately liberation of soul.in tune with Einstein,s Theory $E=m c^{2}$. Even in modern days nearly half the population of the world hold 'flat earth concept', whereas Hinduism is crystal clear on this aspect in Vedas since in Rig Veda the subject of 'Geography' dealing this aspect is named as 'Bhugol' (Spherical Earth) without any ambiguity. Rig Veda also describes the Sun as moving in a chariot drawn by seven horses tied to it by snakes. With niruktam, it means that the seven horses meaning seven rays (VIBGYOR), for, 'Asva' means a ray in Sanskrit, giving out seven rays; tied by snakes in metaphorical sense means the wave form of light.

In the Biography of the Holy Mother Sri Sārada Devi, it is mentioned that the Holy Mother was suffering from Dysentery and Eye trouble being practically blind since all human medicines failed, she tried the chance of obtaining Divine aid. With the help of a friend she went into the temple and laid herself before the Deity in a mood of supplication. Within a short time, the Goddess revealed two medicines, one for Dysentery and the other for Eye trouble. Both the medicines were tried. As a result, within a short time she got back her eyesight that very day, while her other ailments 
disappeared in a short time. As regards the medicine revealed to her by the Goddess she said that she heard the Goddess say to me, "Press out the juice of gourd flowers, mix it with salt and apply it drop by drop to your eyes" Tapasyananda (2014).

This Earth is supposed to possess great curative power. It is doubtful how many Doctors practicing Ayurveda knows this secret and why the all the other doctors in general not try this cure in such given up cases. We have, of course, scientific Hindus and have many Nobel Prize winners to prove the greatness of Hinduism. Unfortunately, all of them mix with those that decry the rich heritage of India and Hinduism. On the contrary, some of the great western scientists have acknowledged the greatness of ancient Hindus and Hinduism. It is more appropriate to cite a few references here for the benefit of my readers.

An early metrical work of Hinduism, 'Manu Smriti', calculates the age of the earth as described in two verses where the age of earth is made about the life span of Brahma. (Brahma is revered as the god of creation in Hinduism). Professor Arthur Holmes, a geologist and a professor at the University of Durham writes in his book, "The Age of Earth" (1913):

"Long before it became a scientific aspiration to estimate the age of the earth, many elaborate systems of the world chronology had been devised by the sages of antiquity. The most remarkable of these occult time-scales is that of the ancient Hindus, whose astonishing concept of the earth's duration has been traced back to 'Manu Smriti', a sacred book."

In the 5th century, the ancient Indians had stated that the earth was 4.3 billion years as compared to the Europeans who believed that our planet was about 100 million years old. But modern science has calculated the age of the earth to be about 4.6 billion years, incredibly close to the 4.3 predicted by the ancients almost 15 centuries earlier. Today, scientists across the world believe that the solar system and the earth is about 4.54 billion years, deciphered by the radiometric reading.

Alan Watts, a Harvard University professor, drew heavily on the insights of Vedānta. Watts became well known in the 1960s as a pioneer in bringing Eastern philosophy to the West. He wrote:

“To the philosophers of India, however, 'Relativity' is no new discovery, just as the concept of light years is no matter for astonishment to people used to thinking of time in millions of kalpas, (A kalpa is about 4,320,000 years). The fact that the wise men of India have not been concerned with technological applications of this knowledge arises from the circumstance that technology is but one of innumerable ways of applying it."

"It is, indeed, a remarkable circumstance that when Western civilization discovers 'Relativity' it applies it to the manufacture of atom-bombs, whereas Oriental civilization applies it to the development of new states of consciousness".

British geneticist and evolutionary biologist, J B S Haldane observed that the Daśāvatārs (ten principal avatars of Lord Vishnu) are a true sequential depiction of the great unfolding of evolution. 
The order of the Daśāvatārs has been interpreted to be reflective of Darwinian evolution. Monier Monier-Williams wrote "Indeed, the Hindus were ... Darwinians centuries before the birth of Darwin, and evolutionists centuries before the doctrine of evolution had been accepted by the Huxleys of our time, and before any word like evolution existed in any language of the world. J. B. S. Haldane suggested that "Daśāvatārs gave a "rough idea" of vertebrate evolution: a fish, a tortoise, a boar, a man-lion, a dwarf and then four men (Kalki is not yet born). He observed that the Dasāvatār (ten principal avatārs of Lord Vishnu) are a true sequential depiction of the great unfolding of evolution. These avatārs of Vishnu show an uncanny similarity to the biological theory of evolution of life on earth. The theory of evolution of man! Hinduism was the first to explain the 'Theory of Evolution'.

In contrast, if we all believe that all the knowledge that we need can be found in Vedas and need only to adhere faithfully to our scriptures, praise and sing in joy of our glorious history and rich heritage, we would not achieve great progress. The underlying idea is to first look up to what the Veda says on any problem and try to explore scientifically only when we can achieve progress and stand tall among all the other countries well advanced in scientific discoveries. For instance, "Vaimanika Sāstra" in Sanskrit meaning Aeronautical Science and the fantastic claim that ancient Indian civilization had developed aeronautical technology centuries before the Wright Brothers flew their first plane. It is a fact. But, as a true Indian Hindu should strive to apply his scientific background unearth the rationale behind the statement.

The universe came into existence with the "Big Bang" and within 2 to 3 minutes of time large volume of Hydrogen, small volumes of Helium and Lithium also originated. Hydrogen is a constituent of the sun, the centre of our solar system, and Hydrogen is also equally found in the central strands of DNA which fact suggests that "Man is a Microcosm of the Macrocosm, the Universe."

\section{REFERENCES}

Bhat, R., \& M. (2010). Signs of Meteors," pp307. Brihat Smhita, 1, $9788120810600-$ 9788120810600 .

Britannica, E. (1994). on "Animal Behaviour". Macropaedia article, 761.

Callahan, M. P., Smith, K. E., Cleaves, H. J., Ruzicka, J., Stern, J. C., Glavin, D. P., House, C. H., \& Dworkin, J. P. (2011). Carbonaceous meteorites contain a wide range of extraterrestrial nucleobases. Proceedings of the National Academy of Sciences, 108(34), 1399513998. Retrieved from https://dx.doi.org/10.1073/pnas.1106493108 10.1073/pnas .1106493108

Ginecol, M. (1997). Pregnant Women Spontaneously Deliver More Often During a Full Moon. The Italian Journal, published a study, 49(3), 91-94.

Hall, J. C., Rosbash, M., \& Young, M. W. (2017). Discoveries of molecular mechanisms controlling the circadian rhythm research. a collection from The Company of Biologists..

Johnson, J. A. (2019). Populating the periodic table: Nucleosynthesis of the elements. Science, 363(6426), 474-478. Retrieved from https://dx.doi.org/10.1126/science.aau9540 10 $.1126 /$ science.aau 9540 
Large, B.-G. (2003). The Devanagari . Text 21, 9, 11. Retrieved from text.www.sanskritweb .net/sansdocs/gita-big.pdf

Rao, Y. (2020a). Human Beings' Birth, Death and Beyond. International Journal of Research -Granthaalayah, 8(9), 404-414.

Rao, Y. (2020b). Human Beings' Birth, Death and Beyond. International Journal of Research -Granthaalayah, 8(9), 404-414.

Rao, Y. (2021). Advanced Panspermia Origin of Life and Evolution. Communicated to Royal Interface Focus Journal.

Rao, Y. V. (2016). Vedic Astrology Reintegrated into Astronomy. In Publ: Sri Venkateswara Vedic University.

Rao, Y. V. (2019). Sunlight in the genesis of principles of Jyotish (A Vedānga. International Journal of Jyotish, 4(2), 2456-4427.

Rao, Y. V. S. (2017a). DNA Finger Printing and Horoscopy for Determining Paternity or Maternity of a Child. Mathematics Letters, 3(5), 53-53. Retrieved from https://dx.doi.org/ 10.11648/j.ml.20170305.13 10.11648/j.ml.20170305.13

Rao, Y. V. S. (2017b). DNA Finger Printing and Horoscopy for Determining Paternity or Maternity of a Child. Mathematics Letters, 3(5), 53-53. Retrieved from https://dx.doi.org/ 10.11648/j.ml.20170305.13 10.11648/j.ml.20170305.13

Rao, Y. V. S. (2019). Definition of Vedic Astrology". International Journal of Research Granthaalayah, 9(3), 102-108.

Tapasyananda, S. (2014). Sri Sarada Devi, The Holy Mother. In Publishers: Ramakrishna Mutt (Vol. 3, pp. 98-98).

"What is Schumann Resonance and why it is important for your Health ... (n.d.). Retrieved from https://www.drskinhealth.com

Women's Menstrual Cycles Begin More Often During a New Moon": The Scandinavian Journal. (1986). Acta Obstet Gynecol Scand. published a study, 65(1), 45-48.

Yeragudipati, V. S. R. (2019). Lunar Magnetism Orchestrates Menstrual Cycle in Symphony of Life. American Journal of Biomedical and Life Sciences, 7(5), 104-104. Retrieved from https://dx.doi.org/10.11648/j.ajbls.20190705.12 10.11648/j.ajbls.20190705.12 